\title{
MAPPING OF AMERY ICE SHELF, ANTARCTICA, SURFACE FEATURES BY SATELLITE ALTIMETRY
}

by

\author{
K.C. Partington, W. Cudlip, N.F. McIntyre and S. King-Hele
}

(Mullard Space Science Laboratory, University College London, Holmbury St. Mary, Dorking, Surrey RH5 6NT, U.K.)

\section{ABSTRACT}

Ice shelves are important regions to observe because they are likely to be sensitive indicators of climatic change. The satellite-borne radar altimetry is highly suited to ice-shelf monitoring; experience with Seasat, which flew in 1978, has demonstrated that a height-measurement precision of the order of $1 \mathrm{~m}$ can be obtained over ice surfaces (Brooks and others 1983).

We identify subtle changes in altimeter wave forms associated with crevassed zones and the grounding line. Normal retracking procedures are shown to be inadequate in detecting such changes, and so methods which provide sensitive indication of the presence of these features in the sampled areas are devised. By ranging to the first return in the echo, the grounding line is identified, and by differencing this measurement with the half-peak power range, a measure of surface roughness is obtained which can be used to detect crevassed zones.

Detection of crevassed shear zones allows delimitation of distinct zones of flow in the ice shelf which can be monitored by future altimeter missions. Monitoring of the grounding-line position can provide sensitive indication of mass-balance conditions over the grounded part of the drainage basin.

\section{INTRODUCTION}

Theoretical studies suggest that ice shelves play a crucial role in maintaining the stability of large regions of the Antarctic ice sheet (Hughes 1973; Thomas and others 1979). Their health, however, is sensitive to the temperature of the ocean and ice-sheet mass-balance conditions (Robin 1979). Early indications of climatic change may therefore be provided by changes in the morphology of the ice shelves. Amongst the surface features which are likely to be responsive indicators of climatic change are shear zones and grounding lines.

Shear zones delimit discrete zones of flow (flow bands) within the ice shelf (Crabtree and Doake 1986). Fluctuations in mass balance within a drainage basin are likely to result in movement of shear zones and changes in flow-band thickness and velocity. Changes in mass balance within a drainage basin may well occur, as suggested by the current stagnation of Ice Stream C in West Antarctica (Shabtaie and Bentley in press), and past surging of Fisher Glacier in the drainage basin of the Amery Ice Shelf, Antarctica (Wellman 1982).

Grounding lines mark the boundary between grounded and floating ice. Weertman (1974) showed that, for an idealized bedrock and perfectly plastic ice sheet, the surface slope across the grounding line must decrease in order to reduce the basal shear stress. The grounding line may therefore be observable on the surface as a distinct feature marked by a sharp change in surface gradient (e.g. Budd and others 1982). However, where the bed in the grounding zone has complex morphology, the transition from fully grounded to fully floating ice may take place over several kilometres (e.g. Stephenson and Doake 1982). As ice shelves are characterized by low surface gradients, the horizontal position of the grounding line is very sensitive to thickness changes in the ice shelf and ice sheet (Weertman 1974).

The detection of these features by remote-sensing techniques would enable their long-term monitoring for climate studies and glaciological applications. Satellite altimeters provide sufficiently precise measurements of surface elevation to detect many surface features. For example, Thomas and others (1983) have demonstrated an ability to monitor the ice-shelf margin using altimeter data. It is the intention of this paper to demonstrate that monitoring of the grounding line and crevassed zones is possible with satellite altimetry.

\section{THE AMERY ICE SHELF}

The study area chosen was the Amery Ice Shelf, since this is the largest Antarctic ice shelf lying within the coverage of Seasat. Further, it is a relatively narrow (c. $250 \mathrm{~km}$ ) outlet for perhaps the fourth largest drainage basin in Antarctica and is therefore likely to be a sensitive indicator of mass-balance changes inland. The estimated area of the drainage basin is $1.63 \times 10^{6} \mathrm{~km}^{2} \pm 4.9 \times 10^{5} \mathrm{~km}^{2}$ (Giovinetto 1964). The mass flux across the ice front has been estimated as $2.7 \times 10^{16} \mathrm{~g}$ year ${ }^{-1} \pm 35 \%$, which discharges at a velocity of $1.2 \mathrm{~km} \mathrm{a}^{-1}$ (Budd 1967; Allison 1979). Approximately one-third of this is contributed by Lambert Glacier, which flows in from the south and is itself fed by several major tributaries which converge about $200 \mathrm{~km}$ south of the grounding line. Wellman (1982) presented geomorphic evidence to suggest that one of these, Fisher Glacier, has surged in the past. Most estimates of mass balance for the basin indicate net accumulation, although recent study has shed doubt on this (McIntyre 1985).

\section{Previous observations}

The Amery Ice Shelf has been the subject of ground, aircraft and satellite survey. Early aerial exploration by Australian National Antarctic Research Expeditions (ANARE) provided information on ice-shelf surface features, including an approximate course for the grounding line (Mellor and McKinnon 1960). The course indicated in the vicinity of Lambert Glacier was oblique to the main direction of flow, and this has recently been confirmed with satellite observations by Swithinbank (in press). Later, ground survey, airborne radio echo-sounding, and drilling were carried out by ANARE to measure ice movement, elevation, accumulation, and thickness in a comprehensive series of studies of the ice shelf in the 1960s and 1970s. These measurements were taken along traverse lines following the approximate centre line of flow, and across the ice shelf near the ice front and near the grounding line (Budd and others 1967; Morgan and Budd 1975; Budd and others 1982). The data produced from these surveys allowed re-assessment of the dynamics of the ice shelf (Budd 1966) and enabled new estimates of the mass balance of the drainage basin to be made (e.g. Budd and others 1967; Allison 1979). Importantly for this study, the position of a grounding point in the vicinity of Lambert Glacier was determined (Budd and others 1982). 
Seasat, which flew in 1978, provided the first coverage by a satellite-borne altimeter, allowing Brooks and others (1983) to produce a topographic map of the ice shelf with a contour interval of $5 \mathrm{~m}$ and an accuracy of the order of $1 \mathrm{~m}$. From the map, they compared corrected altimeter elevations with the centre-line profile obtained by Australian ground survey (Budd and others 1982). The two profiles agree well in shape from near the ice front to near the grounding zone. However, the apparent position of the grounding point, as observed in the altimeter profile, was displaced approximately $40 \mathrm{~km}$ up-stream from the true position, indicating a decrease in the reliability of the altimeter measurements in this region (discussed later). Elsewhere, the presence of crevasses in elevation profiles showed up as zones of rapid elevation fluctuations of amplitude $\pm(4-5) \mathrm{m}$ and wavelength the order of a few kilometres. In addition, the presence of two grounded regions within the ice shelf was indicated by the presence of topographic highs.

\section{THE DATA}

Fifty-seven passes of Seasat altimeter data across the Amery Ice Shelf were available for the present study, including complete coverage from a 17 -day repeat orbit. To validate interpretation of altimeter wave-form data over the Amery Ice Shelf, this study uses digitally enhanced Landsat, AVHRR (Advanced, Very High Resolution Radiometer) imagery and ANARE ground-survey data. Imagery obtained for the ice shelf was digitally enhanced by applying an auto-Gaussian contrast stretch, which forces the frequency histogram of pixel values to take on a Gaussian form. In addition, edge enhancement was carried out to produce an apparent increase in spatial resolution. With a spatial resolution of $1.1 \mathrm{~km}$, crevassed zones are clearly visible after enhancement, and strong flow features can be seen in the region of lower Lambert Glacier, both in Landsat and AVHRR.

\section{Seasat altimeter-range measurements}

The Seasat radar altimeter was designed for use over the open ocean, which can be assumed to be a planar, horizontal, and diffuse scatterer over the area sampled. For such surfaces, information on the surface dielectric and geometric properties within the pulse-limited footprint is contained in the leading edge of the echo wave form (McGoogan 1975). The instrument attempted to locate the centre of the digitizing window at the half-power point of the leading edge, and the range was estimated from the delay time associated with the centre of the sample. The on-board alignment of the digitizing window was carried out by prediction from previous estimates of range and range rate, and was modified by the generation of a height-error signal. As long as the centring was carried out successfully, the calculated range corresponded to the mean elevation within the pulse-limited footprint (Brown 1977). However, the instrument was not designed to track rough and rapidly varying ice-sheet surfaces (Brenner and others 1983; Partington and Rapley 1986).

Fig.1 shows four altimeter wave forms recorded over the Amery Ice Shelf, along with positions on each wave form associated with elevation calculated in four different ways, as discussed below. Wave form 1 is a typical signal received from a flatter part of the ice shelf. The on-board calculated elevation (method a) can be seen to align with the half-power position on the leading edge of the wave form, as a result of the low and slowly varying relief of the surface. The lengthened leading edge of wave form 2 suggests that it is from a rougher region of the ice shelf. The tracker again finds the half-power position because the surface elevation is varying slowly along track and the wave form similar in shape to rough ocean return. The complexity of wave forms 3 and 4 suggests that they are from geometrically more complex surfaces. Wave form 3 is double-ramped, suggesting the presence of two distinct reflecting regions in the sampled area. Wave form 4 is still more complex and difficult to interpret, with the leading edge hard to define. Areas contributing to the pulse-limited footprint in such cases may be spatially separated and variable in scattering properties and relief (Griffiths 1984).
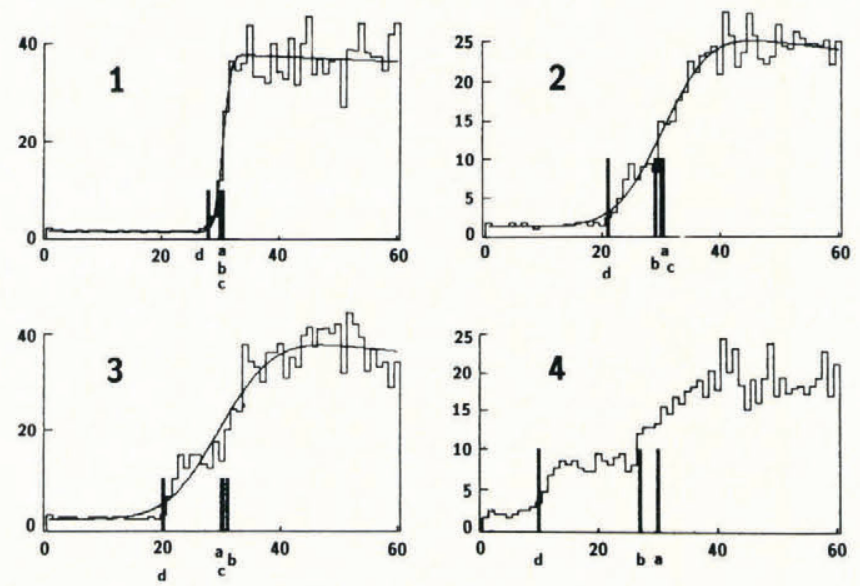

Fig.1. Four ice-shelf wave forms with position ranged to by the on-board tracker (a), half-peak power retracked elevation (b), least-squares fitting of a model ocean return (c), and first-return retracked elevation (d).

Wave forms 3 and 4 were given poor elevation estimates by the on-board tracker.

\section{Retracking methods}

As the on-board tracker often failed to align the centre of the digitizing window with the half-power point of the leading edge, it is normally necessary to re-align these so that a more suitable position on the wave form is selected. Three methods have been reported in the literature to date.

Brooks and others (1983) retracked to the half-peak value in the wave form (Fig.1, method b) to produce their topographic map of the Amery Ice Shelf. For ocean return, this produces a range to the half-power position of the leading edge. Wave form 1 is successfully retracked using the half-peak method. The low slope of the leading edge of wave form 2, however, results in increased sensitivity to noise. Wave form 3 shows that the retracked elevation obtained from double-ramped wave forms is very sensitive to the relative amplitudes of the two ramps. In this case, it is the second ramp which is ranged to. A gradual increase in the amplitude of the first ramp relative to the second along a sequence of double-ramped wave forms would result in a spurious step in the elevation profile. The profiles of elevation produced by Brooks and others (1983) across crevassed zones may well suffer from this problem and therefore may not represent the true surface.

Martin and others (1983) used a more sophisticated retracking technique (method c). The model ocean wave form assumed in design of the on-board tracking procedure (Brown 1977) was fitted to altimeter ice-sheet data by the method of least squares. They also used a "double-ramp" model to fit wave forms of type 3 (Fig.1), so that two range estimates could be made. Compared with the halfpeak method, this technique results in reduced sensitivity to noise. In addition, the method provides several parameters which may be used to describe wave-form shape, including leading-edge width, which have not been used to extract information on surface character to date. A similar version of the single-ramp model has been implemented for least-squares fitting in this study, for comparative purposes.

Methods a to $c$ all assume that the return is oceanlike, which is not necessarily appropriate for detection of subtle changes in wave-form shape associated with passage across surface features such as crevassed zones and the grounding line.

Martin and others (1983) attempted to overcome this problem by fitting a double-ramp model wave form to return from more complex surfaces. Where the wave form exhibits a form which implies return from two distinct reflecting surfaces, then this method works well. However, visual inspection of returns from the Amery Ice Shelf indicates that many wave forms fail to fall into the "oceanlike" or "double-ramp" categories. 
Thomas and others (1983) used a different retracking method to enable them to map the ice margin. They showed that the location of the ice margin could be determined from the position at which the return signal from sea ice begins a parabolic migration away from the satellite. In order to demonstrate this, they retracked the altimeter data to the first return associated with the sea ice, in a signal which contained returns from both sea ice and ice shelf. The retracked elevation then referred to the closest part of that surface to the satellite, and was a spot measurement rather than a mean over an area.

\section{First-return retracking}

A new method of retracking adopted here (d in Fig.1) is specially designed to provide meaningful elevation measurements over rougher ice-shelf topography, where the other methods, which assume an ocean return, produce highly ambiguous measurements. The method ranges to the first-return signal in the wave form, so providing a spot elevation measurement associated with the closest surface to the satellite.

The method used to retrack data employs a threshold retracker set at a value of ten "counts" (undimensionalized units of signal amplitude). Seasat used an on-board automatic gain control to attenuate the signal and keep it within the dynamic range of the instrument (Townsend 1980). Counts are the signal-amplitude units after application of automatic gain control to the signal. Over the main body of the Amery Ice Shelf, the signal-amplitude value varied little, so noise was held at a fairly constant count level. This allowed the use of a signal-count value to detect the first return.

The first-return method results in a higher elevation value than other retracking methods, the difference being proportional to the width of the leading edge for an ocean return (Fig.1, wave forms 1 and 2). The method is particularly useful, however, for retracking of complex wave forms such as 3 and 4 . Here, definition of the area of the surface contributing to the leading edge of the return is not

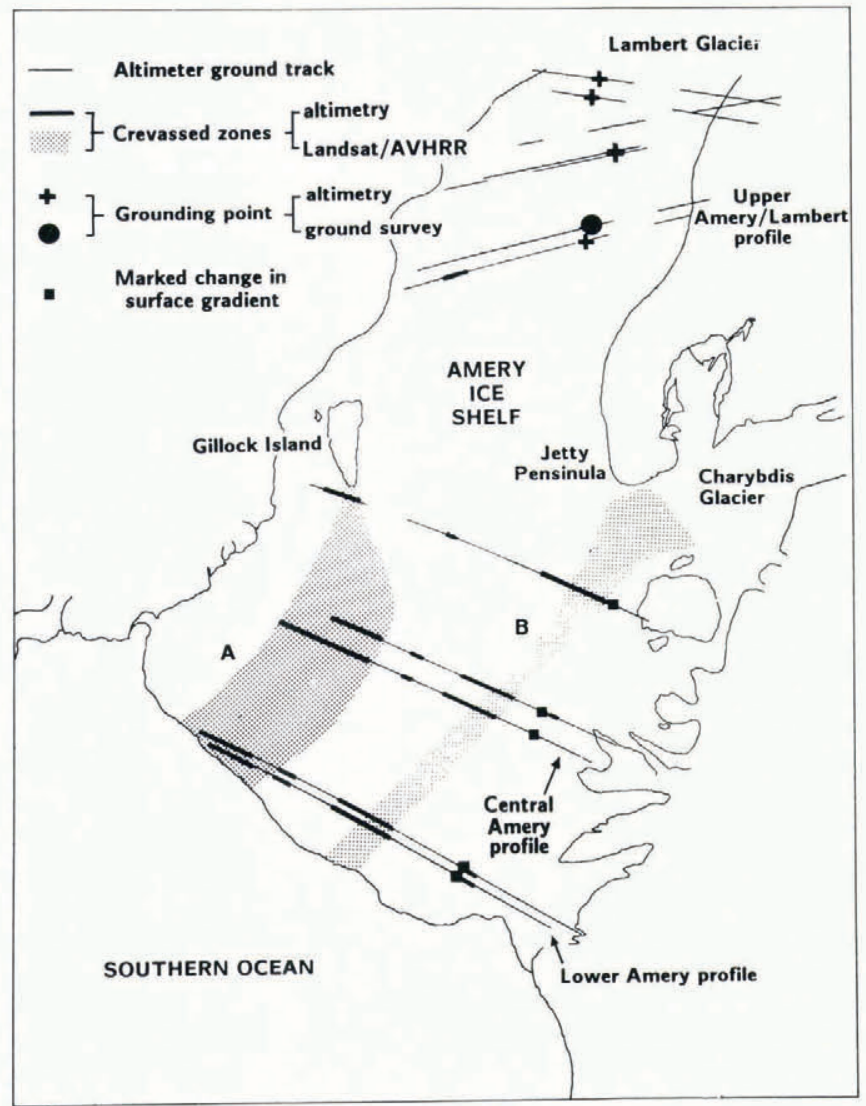

Fig.2. Map of the Amery Ice Shelf showing surface features positioned by satellite altimetry, together with features identified from imagery and ground survey (Budd and others 1982). required, so easing interpretation, though the closest surface to the satellite may not lie at nadir. Such cases may be flagged by the presence of parabolic sections in elevation profiles, suggesting that the retracking method is ranging to a single surface feature as the satellite approaches and recedes (Gundestrup and others 1986).

\section{RESULTS}

Fig. 2 shows a map of the Amery Ice Shelf and lower Lambert Glacier. Five altimeter tracks pass within $5 \mathrm{~km}$ of the grounding point identified by Budd and others (1982), and marked on Fig.2 by a circle. Several tracks of altimeter data cross crevassed zones propagating down-stream from Gillock Island (A) and Charybdis Glacier/Jetty Peninsula (B), and these zones can be seen in digitally enhanced Landsat and AVHRR imagery.

\section{Crevassed zones}

Fig.3b shows a sequence of wave forms recorded during satellite passage across crevassed area B, which delimits flow originating from Charybdis and Lambert

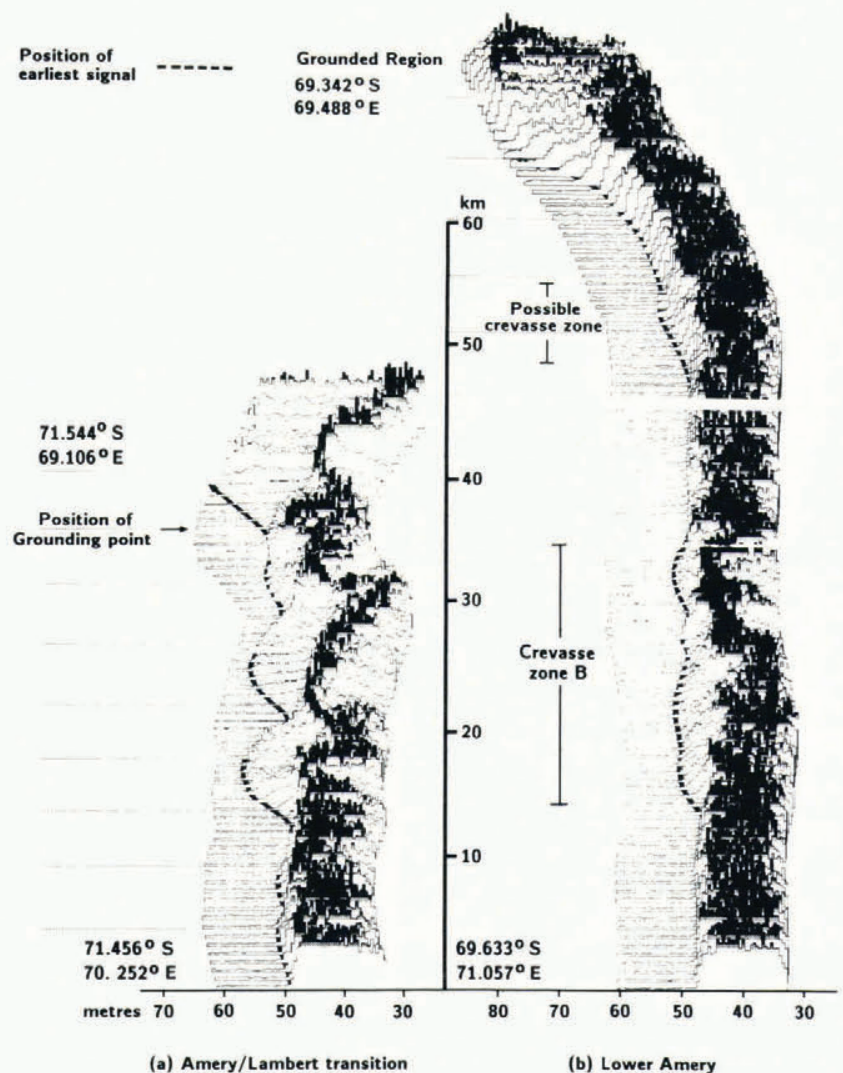

Fig.3. Two altimeter wave-form sequences shown crossing the Amery Ice Shelf from east to west (bottom to top of the plot). Each wave form is a histogram of received signal power (z-axis) against time/range (with non-absolute scale shown across base of plot). The wave forms overlap and are scaled to force the peak value of each wave form to be the same height. The high-amplitude parts of the wave forms are shaded to emphasize the passage of migrating features through the sequence.

Glaciers. The crevassed area is clearly marked by an increase in the width of the leading edge of the wave forms, and by an increase in surface elevation indicated by the position of the first return. Over crevassed surfaces the precise nature of the relationship between surface roughness and leading edge is likely to be complex and therefore lead to difficulties in the interpretation of any elevation measurements which assume an ocean return (e.g. Brooks and others 1983).

The plot suggests that crevassed zones may be delimited 
by measurement of leading-edge width. One such measurement is provided as a by-product from least-squares fitting of a model ocean return to the data (Martin and others 1983). However, the complex wave forms found in crevassed areas often defeat the fitting procedure, which either fails to converge iteratively or produces a poor fit. Another measure of leading-edge width is provided by significant wave height, which is automatically telemetered from the satellite. However, this measure is damped by a $0.8 \mathrm{~s}$ time constant, so tends to be insensitive. The most reliable method was found to be a difference between the first-return and the half-peak elevations. Fig. 4 shows three transects across the Amery Ice Shelf, each containing the

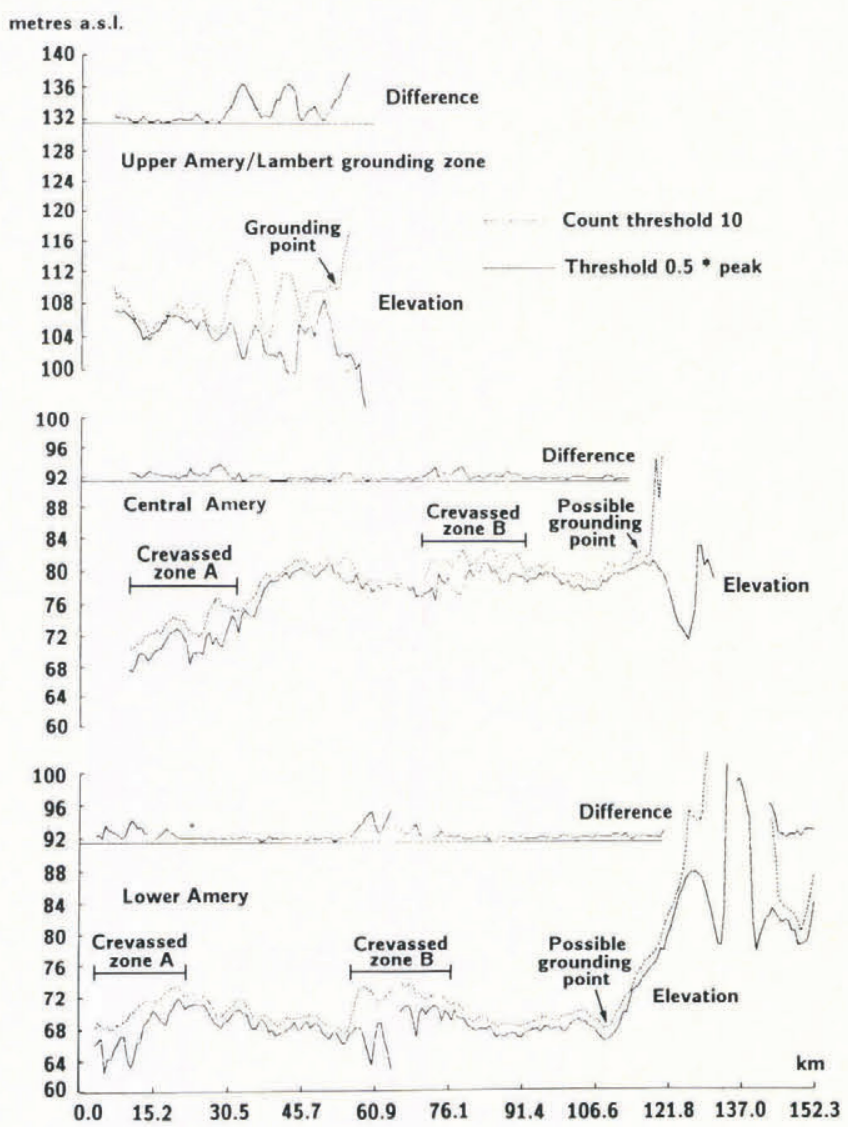

Fig.4. Three transects of altimeter-derived surface elevation across the Amery Ice Shelf. Each transect contains two profiles obtained from first-return and half-peak retracked elevations.

first-return and the half-peak elevations along with the difference between the two. Zones of crevassing are indicated by a large difference between the two values, with the contrast between crevassed and non-crevassed regions most clear in the lower regions of the ice shelf.

This latter technique is sufficiently sensitive to detect regions of possible crevassing on the ice shelf which are not visible in digitally enhanced AVHRR and Landsat data. An example can be seen in Fig. $3 \mathrm{~b}$, at the position of a marked change in surface gradient. The leading edge of the wave form increases in width, suggesting that a zone of crevasses may be located at this position. The possible shear zone can be detected intermittently along the western side of the ice shelf north of Charybdis Glacier in other sequences of altimeter data. Flow lines visible in AVHRR imagery show that its location is consistent with that of the edge of a relatively stagnant region determined from velocity measurements in the extreme north-west of the ice shelf (Budd and others 1982). Other possible crevassed zones are indicated by bold sections of ground tracks in Fig.2. The criterion for delimitation of crevassed zones for this map was a difference of $1.5 \mathrm{~m}$ in the elevations as determined by the first-return and half-peak methods, on purely empirical grounds.
Flow bands are delimited by shear zones. In Fig.4, two flow bands are visible, separated by crevassed zone B Repeated measurements of the elevations and widths of flow bands delimited by shear zones can be used to infer mass-balance conditions within sub-catchments.

Measured widths of the leading edge cannot, however, be used indiscriminately to detect crevassed zones. There are a number of realistic surface geometries and scattering properties which can combine to produce similar wave forms and not all of these are crevassed surfaces. For example, the transect across the Amery Ice Shelf/Lambert Glacier transition region (Fig.4) shows a large and fluctuating difference between the first-return and half-peak elevations. The first-return elevation can be seen to follow a parabolic trajectory in two places, which indicates that a single surface feature, rather than the nadir surface, is being ranged to (Gundestrup and others 1986). For this reason, initial detection of shear zones using altimetry requires validation from imagery, either from direct confirmation of the presence of crevasses or from the use of flow lines to indicate that a likely shear zone lies down-stream of a promontory or glacier confluence.

\section{The grounding line}

Fig. 3 shows a sequence of wave forms over the grounding zone of Lambert Glacier. A grounding point (at station T4) identified by Budd and others (1967) is located approximately $4 \mathrm{~km}$ to the north of the closest approach of the ground track at the position indicated. The closest approach of the satellite to the grounding point is marked by a sharp change in surface gradient indicated by the position of the first return. In addition, the wave forms in the vicinity of the grounding point show an evolution similar to those generated by simulation over a change in slope (Rapley and others 1985).

Fig.5 shows profiles of on-board height and three retracking heights along a track in the vicinity of the grounding point at $\mathrm{T} 4$. The first-return retracking method

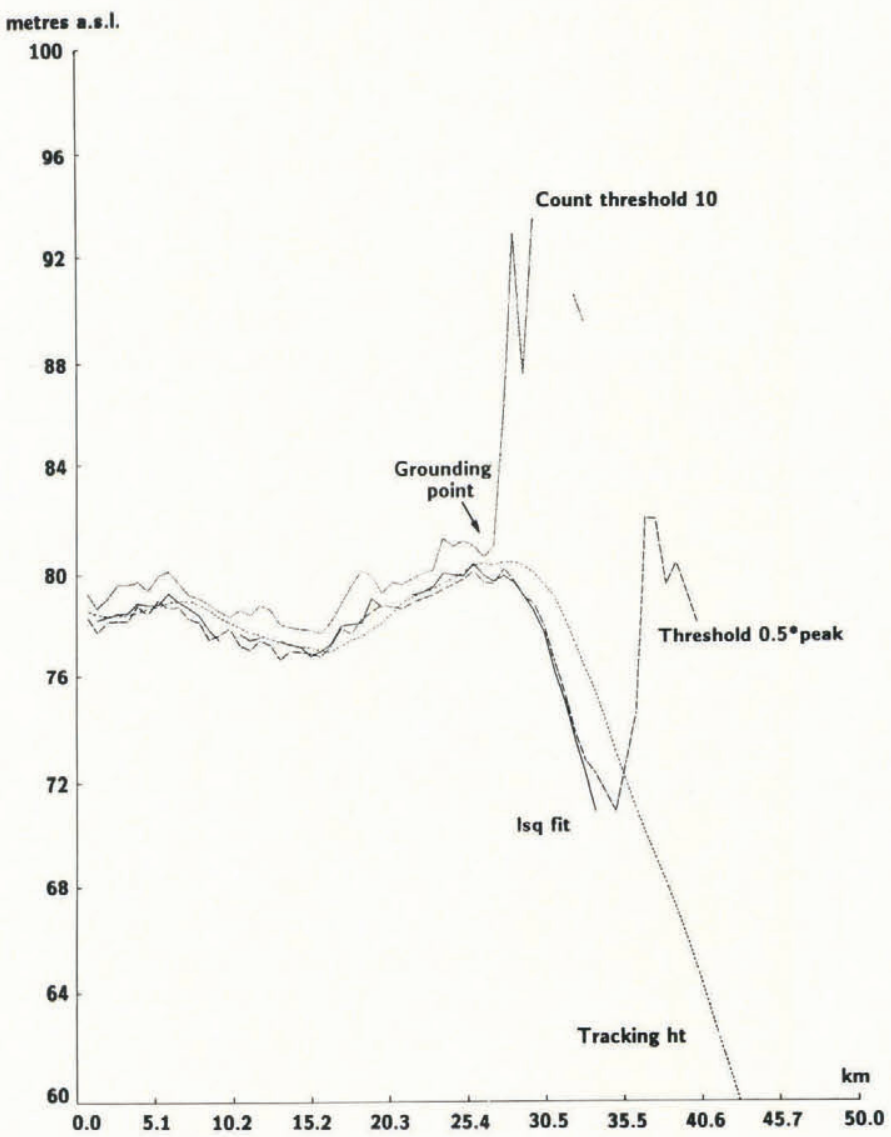

Fig.5. Profiles of on-board tracking height and three types of retracked elevation in the region of the grounding point (T4) reported by Budd and others (1982) for Lambert Glacier. 
produces a profile of the nearest surface to the satellite as a series of spot measurements. With low surface slopes, this will be a good representation of the sub-satellite surface. The other profiles in Fig.5 show a decrease in surface elevation in the vicinity of the grounding line, which in each case is principally the result of assuming a model ocean return. As the return is focussed by the surface geometry associated with the change in slope, these methods continue to produce range measurements to the grounding zone after passing over the grounded ice. This demonstrates that the first-return method is the only reliable method for ranging across the grounding line.

Fig.4a shows a longer profile of the same track, with elevation associated with the first-return and half-peak methods. In addition to a grounding point, the first-return profile indicates the presence of two features sampled from off nadir, as discussed in the previous section. It is possible that these are grounded regions located to one side of the ground track, which would suggest that the grounding line is "wavy" in form.

Two methods are available for locating the position of the change in slope associated with the grounding line. The first utilizes the first-return method and applies correction. The second employs the method of Thomas and others (1983) to locate the position at which return from the grounding zone begins a parabolic migration away from the satellite.

The grounded ice is detected prior to the satellite being positioned directly above it, and is detected by the first-return method as a "toe" moving out of the main ramp associated with the floating surface. Assuming the grounding line is a straight line separating two planar surfaces, the grounding line will be located by the first-return method a distance $d$ before its true position on the satellite ground track where:

$$
\mathrm{d}=\frac{\mathrm{h} \tan (\alpha / 2)}{\sin \beta}
$$

or

$$
\mathrm{d}=\frac{\mathrm{hm}}{2 \mathrm{n} \sin ^{2} \beta}
$$

Here, $h$ is the distance of the satellite from a floating surface, $\alpha$ is the slope of the grounded surface, $B$ is the angle of incidence of the satellite with the grounding line, $\mathrm{m}$ is the elevation difference in metres between consecutive wave-form first returns, and $\mathrm{n}$ is the along-track distance between wave-form samples $(662 \mathrm{~m})$. For a horizontal floating ice surface, a grounded ice gradient of $0.29^{\circ}$ (Table I and Fig.3a), a $B$ value of $90^{\circ}$ and an $h$ value of $800 \mathrm{~km}$,

\section{TABLE I. GRADIENTS EITHER SIDE OF GROUNDING POINT (MEAN OVER $12 \mathrm{~km}$ )}

$\begin{array}{lll}\text { Upper Amery Ice Shelf } & 6.1 \times 10^{-3^{\circ}} & 2.9 \times 10^{-1^{\circ}} \\ \text { Central Amery Ice Shelf } & 1.4 \times 10^{-2^{\circ}} & 2.9 \times 10^{-1^{\circ}} \\ \text { Lower Amery Ice Shelf } & 9.9 \times 10^{-3^{\circ}} & \end{array}$

d is $2025 \mathrm{~m}$. The slopes associated with the floating ice in these areas will have a negligible effect on the magnitude of d. Where the satellite does not cross the grounding-line at right-angles, the estimated slope will be lower than it actually is, leading to an underestimate of d. In the example given above, the value of $d$ will increase to $2338 \mathrm{~m}$ for an approach angle of $60^{\circ}$ to the grounding line, and to $4049 \mathrm{~m}$ for an approach angle of $30^{\circ}$. In principle, it is possible to gain a first-order estimate of the angle of incidence of the altimeter from the first-order estimate of the grounding-line position and iterate towards its true position where ground-track density is high enough.

In view of the limitations on accuracies achievable in positioning of the grounding point using this method alone, it is useful to employ an additional method analogous to that employed by Thomas and others (1983) in their mapping of the ice margin. They ranged to the earliest signal associated with the lower (sea-ice) surface on approach to the ice shelf. The point at which this began a parabolic trajectory away from the satellite marked the position of the ice margin. Although the grounding line in this case is a change in slope rather than a step, the same technique can be applied here to provide an additional measure of the grounding-point position. In the example given above (Fig.3a), the earliest signal associated with the grounding zone begins a parabolic trajectory away from the satellite at a distance of $2648 \mathrm{~m}$ beyond the uncorrected estimation of the grounding-line position obtained from the first-return method. The near-parabolic profile produced by two retracked elevations and on-board calculated elevation can be seen in Fig.5. All three methods continue to track to the grounding zone once the satellite has passed on to the grounded ice.

In the example above, the two techniques produce a discrepancy of $623 \mathrm{~m}$, assuming the grounding line is at right-angles to the altimeter ground track. The accuracies achievable are limited by the along-track distance between wave-form samples and by the rough nature of the surface, which causes the assumptions behind the techniques to break down. The accuracies in positioning the beginning of the parabolic trajectory and positioning of the increase in surface gradient are each of the order of half the distance between wave-form samples along track $(331 \mathrm{~m})$. This places the discrepancy of $623 \mathrm{~m}$ within the maximum expected $(662 \mathrm{~m})$. The rough nature of the surface will cause additional errors in estimation of the beginning of the parabolic trajectory and in estimation of surface gradient, which may decrease accuracies substantially when the satellite crosses the grounding line obliquely. Along the track closest to T4, these methods produce a location for the grounding line approximately $2.8 \mathrm{~km}$ to the north-east, with an accuracy in location of the order of $\pm 500 \mathrm{~m}$.

\section{ACKNOWLEDGEMENTS}

The authors would like to acknowledge the help of R.H. Merson of the National Remote Sensing Centre in processing and preparation of AVHRR imagery.

\section{REFERENCES}

Allison I 1979 The mass budget of the Lambert Glacier drainage basin, Antarctica. Journal of Glaciology 22(87): 223-235

Brenner A C, Bindschadler R A, Thomas R H, Zwally H J 1983 Slope-induced errors in radar altimetry over continental ice sheets. Journal of Geophysical Research 88(C3): 1617-1623

Brooks R L, Williams $R$ S Jr, Ferrigno $J$ G, Krabil W B 1983 Amery Ice Shelf topography from satellite radar altimetry. In Oliver $\mathrm{R}$ L, James $\mathrm{P}$ R, Jago $\mathrm{J}$ B (eds) Antarctic earth science. Canberra, Australian Academy of Science: 441-445

Brown G S 1977 The average impulse response of a rough surface and its applications. IEEE Transactions on Antennas and Propagation AP 25(1): 67-74

Budd W F 1966 The dynamics of the Amery Ice Shelf. Journal of Glaciology 6(45): 335-358

Budd W F, Smith I L, Wishart E 1967 The Amery Ice Shelf. In Oura $\mathrm{H}$ (ed) Physics of Snow and Ice: International Conference on Low Temperature Science ... 1966 ... Proceedings, Vol 1, Pt 1. [Sapporo], Hokkaido University. Institute of Low Temperature Science: 447-467

Budd W F, Corry M J, Jacka T H 1982 Results from the Amery Ice Shelf Project. Annals of Glaciology 3: 36-41

Crabtree R D, Doake C S M 1986 Radio-echo investigations of Ronne Ice Shelf. Annals of Glaciology 8: 37-41 
Giovinetto M B 1964 The drainage systems of Antarctica: accumulation. In Mellor $\mathrm{M}$ (ed) Antarctic snow and ice studies. Washington, DC, American Geophysical Union: 127-155 (Antarctic Research Series 2)

Griffiths H 1984 Special difficulties of retrieving surface elevation over continental ice. In Guyenne T D, Hunt J J (eds) ERS-1 Radar Altimeter Data Products; proceedings of an ESA workshop held at Frascati, Italy, on 8-11 May, 1984. Paris, European Space Agency: 61-65

Gundestrup N S, Bindschadler R A, Zwally H J 1986 Seasat range measurements verified on a 3-D ice sheet. Annals of Glaciology 8: 69-72

Hughes T J 1973 Is the West Antarctic ice sheet disintegrating? Journal of Geophysical Research 78(33): 7884-7910

McGoogan J T 1975 Satellite altimetry applications. IEEE Transactions on Microwave Theory and Techniques MTT 23 (12): $970-978$

McIntyre N F 1985 A re-assessment of the mass balance of the Lambert Glacier drainage basin, Antarctica. Journal of Glaciology 31(107): 34-38

Martin T V, Zwally H J, Brenner A C, Bindschadler R A 1983 Analysis and retracking of continental ice sheet radar altimeter waveforms. Journal of Geophysical Research 88(C3): 1608-1616

Mellor M, McKinnon G 1960 The Amery Ice Shelf and its hinterland. Polar Record 10(64): 30-34

Morgan V I, Budd W F 1975 Radio-echo sounding of the Lambert Glacier basin. Journal of Glaciology 15(73): 103-111

Partington K C, Rapley C G 1986 Analysis and simulation of altimeter performance for the production of ice sheet topographic maps. Annals of Glaciology 8: 141-145

Rapley C G and 16 others 1985 Applications and scientific uses of ERS-1 radar altimeter data; final report. Noordwijk, European Space Agency

Robin G de Q 1975 Ice shelves and ice flow. Nature 253(5488): 168-172

Robin G de Q 1979 Formation, flow, and disintegration of ice shelves. Journal of Glaciology 24(90): 259-271

Shabtaie S, Bentley C R In press Mass balance of the Ross embayment ice streams, West Antarctica. Journal of Geophysical Research

Stephenson S N, Doake C S M 1982 Dynamic behaviour of Rutford Ice Stream. Annals of Glaciology 3: 295-299

Swithinbank C W M In press Do Antarctic ice streams surge? Journal of Geophysical Research

Thomas R H 1973 The creep of ice shelves: interpretation of observed behaviour. Journal of Glaciology 12(64): 55-70

Thomas R H, Sanderson T J O, Rose K E 1979 Effect of climatic warming on the West Antarctic ice sheet. Nature 277 (5695): 355-358

Thomas R H, Martin T V, Zwally H J 1983 Mapping the ice-sheet margins from radar altimetry data. Annals of Glaciology 4: 283-288

Townsend W F 1980 An initial assessment of the performance achieved by the Seasat-1 radar altimeter. IEEE Journal of Oceanic Engineering OE 5(2): 80-92

Weertman J 1974 Stability of the junction of an ice sheet and an ice shelf. Journal of Glaciology 13(67): 3-11

Wellman P 1982 Surging of Fisher Glacier, eastern Antarctica: evidence from geomorphology. Journal of Glaciology 28(98): 23-28

Zwally $\mathrm{H} \mathrm{J}$, Bindschadler R A, Brenner A C, Martin T V, Thomas R H 1983 Surface elevation contours of Greenland and Antarctic ice sheets. Journal of Geophysical Research 88(C3): 1589-1596 